\title{
CREATION OF OPTIMAL SELECTION-TECHNOLOGICAL MODEL COW OF PRODUCTION TYPE BASED ON HOLSTEIN GENOTYPE
}

\author{
Vladimir Trukhachev, Sergei Oliinyk, Nikolai Zlidnev \\ Stavropol State Agrarian University, Russia \\ scopush@gmail.com
}

\begin{abstract}
Based on the recommendation of adaptation the ICAR a regional management model of high-yielding genetic resources of animal husbandry in dairy farming was developed, which has been tested in the ICAR Secretariat and at the national level of the Russian Federation. For developing the optimal selectiontechnological model cow of the production type based on Holstein genotype the interaction of the control assistant and evaluation service, laboratory for milk quality selection control and genetic control was used. Using highly productive bulls of Holstein breed is one of the main directions into improvement the productive and technological characteristics of the dairy cattle of local genotypes. In the recent years, thanks to extension of the livestock genetic research, it was considered useful to monitor the distribution of genetic abnormalities BLAD, CVM, DUMPS, BC, BY, FXID; studies of lethal haplotypes HH1, HH3, HH4, HH5, AH1, associated with impaired fertility, lack of cholesterol HCD and shortened spermatic filament syndrome ARMC3B. An integrated approach allows developing recommendations to the selection of parental pairs, to improvement the exteriorconstitutional features, and excluding from the breeding process the male and female parent; who are genetic abnormalities carriers associated with impaired cow fertility.
\end{abstract}

Keywords: dairy cattle, selection process model, milk production.

\section{Introduction}

An important factor of ensuring a steady trend of positive development of dairy cattle breeding in the Russian Federation and in the Stavropol Territory is implementation of modern techniques of herd management, which are proved by international practices. They are based on the application of the recommendations of the International Committee for Animal Recording (ICAR) [1-3].

Purposeful work on the harmonization of national regulatory frameworks with international law is carried out in the Russian Federation. One of the stages of this process is implementation of the research project at the Stavropol State Agrarian University, which is particularly significant for the agro-industrial complex of the Russian Federation in the context of ensuring import substitution in animal husbandry (genetic material). The research aim was to develop a regional model of the formation and management of highly productive livestock genetic resources (on the example of Stavropol Territory). For this purpose, there was the Center of management of highly productive genetic resources of livestock established with the structure: expert-appraisal service; controlassistance service; reference-laboratory; genetic control laboratory.

The objectives of the study were to develop guidelines for the animal recording in compliance with the requirements of the ICAR to provide national report, to improve interaction between different departments of the Centre and milk producers, and development of the optimal selection process model of a production type cow on the basis of Holstein genotypes.

Works were carried out on the leading breed livestock farms of the Stavropol Territory in the North Caucasian Federal District of the Russian Federation [4-9].

\section{Materials and methods}

The material for the research was the Russian and foreign standard documentation for dairy cattle recording. There are highly productive dairy cattle of different age and gender groups, cow-heifers in the first, second and third lactation in the number of 1256 of the basic breeds of animals: Holstein black-and-white, black-and-white, Ayrshire. Methods of zootechnical and comparative analysis, linear estimation techniques for exterior features of Holstein cows and Holstein genotypes were used for the research.

The evaluation of actual manifestation phenotypic (externally-constitutional) signs in cows was carried out by linear evaluation of external characteristics of the Holstein cows and golshtinized genotypes in accordance with the requirements of the Russian legislation and ICAR [3]. 


\section{Results and discussion}

Based on the study of Russian and foreign standard documentation for the recording of dairy cattle breeding, guidelines for the organization of the departments of the regional selection and process center have been developed, which include conducting linear estimation articles of the body (Expertappraisal Service) and the account of milk production of cows (control -assistant service), quality evaluation of milk with Russian and foreign reference methods (laboratory breeding of milk quality control), assessment of genetic abnormalities using cytogenetic methods and PCR-based diagnostics (genetic control laboratory). It was found that at the regional level it is necessary to carry out accounting of milk production according to the forms 1-4, which are provided by the ICAR recommendations.

Recording of cattle milk productivity and selection of the individual samples of raw milk for quality research in the laboratory of the selective control of milk quality are carried out by experts of control-assistance service with the use of milk counters with sampling tubes, which are approved by the ICAR: Waikato, DeLaval MM6, Metatron (Flap) GEA Farm Technologies. As a result of purposeful work of scholars and practitioners of livestock breeding in the Stavropol Territory on the basis of the best breeding farms there were highly productive genetic resources of the most technological dairy breeds established (Table 1).

\section{Indicators of milk productivity of breed genetic resources}

Table 1 of Stavropol Territory (Russian reproduction)

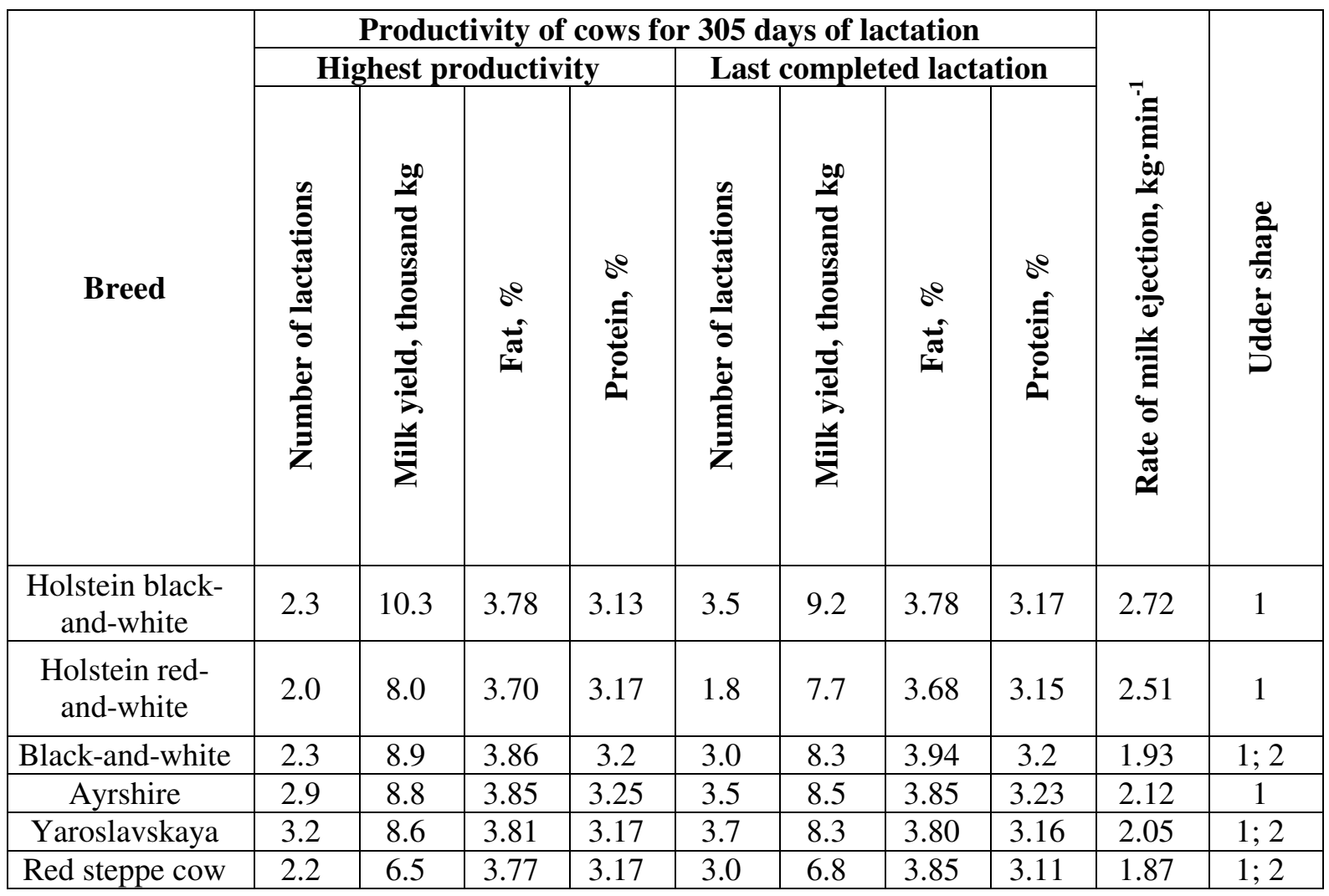

Analysis of the data shows that the milk yields of the given animal populations are at the level of the best achievements of dairy farms of the EU, USA and Canada [4]. Thus, the genetic potential of the world's best dairy cattle breeds enables development of regional programs to increase milk production and, thereby, increase the food security of the region. 
Methods of determining milk quality

\begin{tabular}{|c|c|c|}
\hline Indicator & Normative documents of the RF & ICAR reference-methods (2014) \\
\hline Fat & $\begin{array}{l}\text { GOST R ISO 2446-2011 - Milk. } \\
\text { Method for determination of the fat } \\
\text { content (The Gerber Method) }\end{array}$ & $\begin{array}{c}\text { Gravimetric method } \\
\text { (Gravimetric method, Röse-Gottlieb) ISO } \\
1211 \\
\text { Butyrometric method ISO } 2446\end{array}$ \\
\hline Protein & $\begin{array}{l}\text { GOST } 23327-98 \text { MILK and dairy } \\
\text { products (The Kjeldahl method) }\end{array}$ & $\begin{array}{c}\text { Titrimetric method } \\
\text { (Titrimetric method, Kjeldahl) ISO } 8968 \\
\text { Dye-binding, Amido Black ISO } 5542\end{array}$ \\
\hline $\begin{array}{l}\text { Somatic } \\
\text { cells }\end{array}$ & $\begin{array}{l}\text { GOST R 54077-2010 - Milk. Methods } \\
\text { for determination of the number of } \\
\text { somatic cells by the changing of } \\
\text { viscosity } \\
\text { GOST R ISO 13366-1-2010 «Milk. } \\
\text { Determination of the number of somatic } \\
\text { cells. Part 1. Microscope method } \\
\text { (Control method)» }\end{array}$ & $\begin{array}{l}\text { Microscope Reference method ISO 13366- } \\
1 \\
\text { Electronic particle counter ISO } 13366 \\
\text { Fluoro-opto-electronic method (Rotating } \\
\text { disk) ISO 13366-3 }\end{array}$ \\
\hline
\end{tabular}

Assessment of the quality of milk from animals is carried out under the control of the laboratory of the selective control of milk quality in accordance with the relevant regulations of the Russian Federation and with the ICAR recommendations [2,4] (Table. 2). Data analysis of Table 2 shows that domestic and foreign reference methods substantially coincide for determining quality indicators of milk protein, fat and somatic cells. At the same time, when determining somatic cells in the Russian Federation it is allowed using indirect methods using drugs «Mastoprim» and viscosity measurement.

Comprehensive assessment of pedigree and economically useful parameters of dairy and dualpurpose cattle is carried out by experts of the expert-appraisal service of the regional breeding and technology center and includes linear measurement of the body type and appraisal $[1 ; 2 ; 4]$.

Using high-producing bulls for service of the Holstein breed is one of the main ways in improving the technological and productive characteristics of the local genotypes of dairy cattle. At the same time, in recent years thanks to the spread of the practice of genetic research of animal husbandry and according to the results of the monitoring, the presence of some breeding pairs of genetic abnormalities is established, such as BLAD, CVM, DUMPS, BC, BY, FXID, lethal haplotypes HH1, $\mathrm{HH} 3, \mathrm{HH} 4, \mathrm{HH} 5, \mathrm{AH} 1$, which are associated with impaired fertility; haplotype is associated with a lack of HCD cholesterol; haplotype is associated with the syndrome of shortened spermatic filament ARMC3B.

Based on the recommendations of linear assessment of the highly productive first-stage cows, the average characteristics of the model animal were calculated: the score of the sign "length of the sacrum" was $4.59 \pm 0.04$ (points); breast width: $4.51 \pm 0.04$; breast depth: $5.23 \pm 0.04$; angularity of the ribs: $4.79 \pm 0.04$; hind legs, rear view: $5.01 \pm 0.03$; hind legs, side view: 4.28 ą 0.04 ; angle of hoof setting: $3.86 \pm 0.04$; hock joint condition: $4.69 \pm 0.05$; thickness of the terminal bone: $6.4 \pm 0.04$; fastening of the udder in the front: $3.66 \pm 0.05$; height of udder: $4.45 \pm 0.05$; udder support width: 4.48 \pm 0.05 ; supporting ligament: $5.19 \pm 0.06$; udder depth: $6.17+0.05$; placement of the front nipples: $4.30 \pm 0.04$; length of the front nipples: $5.20 \pm 0.04$; thickness of the front nipples: $5.12 \pm 0.04$; location of the posterior nipples: $5.43 \pm 0.05$.

In order to achieve the optimal "5-7-score" ratio in the dairy herds of the Stavropol Territory, it is necessary to use bulls-producers with a prepotent method in the breeding system. 1.5-2.0 of the standard deviation. In this case, bulls-producers should be free from the manifestation of known genetic anomalies.

\section{Conclusions}

1. Using the ICAR method in selecting high-performance parental pairs into direction of improving the external and constitutional characteristics in dairy cattle allows for the exclusion of paternal and material individuals from the breeding process that carry genetic abnormalities associated 
with impaired fertility in cows: BLAD, CVM, DUMPS, BC, BY, FXID, HCD, ARMC3B, fatal haplotypes HH1, HH3, HH4, HH5.

2. When selecting parental pairs in populations of highly productive dairy cattle golshtin genotypes of the Stavropol Territory, bulls-producers should be used without known genetic anomalies, as well as with a prepotent method to improve the quality of the linear characteristics of the body by "udder status" and "limb status" at least 1.5-2.0 of the standard deviation.

\section{References}

1. Gaworski M., Leola A. Effect of technical and biological potential on dairy production development. Agronomy Research, 2014. 12 (1), pp. 215-222.

2. Mottram T. T., Lowe J., McGowan M., Phillips N. Technical note: A wireless telemetric method of monitoring clinical acidosis in dairy cows. Computer Electronics Agriculture, vol. 64, 2008, pp. 45-48.

3. Trukhachev V.I., Oleinik S.A., Zlydnev N.Z., Morozov V.Yu. Application of the recommendations of the international committee for animal recording (ICAR) in assessing the yields of dairy cattle in Russia. Research Journal of Pharmaceutical, Biological and Chemical Sciences. 2015;6(6), pp. 1314-1316.

4. Belle Z., André G., Pompe J.C.A.M. Effect of automatic feeding of total mixed rations on the diurnal visiting pattern of dairy cows to an automatic milking system. Biosystems Engineering, vol. 111, 2012, pp. 33-39.

5. Sadovoy, V., Omarov, R., Shlykov, S., Shchedrina, T. Assessment compliance of qualitative food characteristics to standard requirements. 15th International Scientific Conference on Engineering for Rural Development, May 25-27, 2016, Jelgava, Latvia, pp. 360-363.

6. Bewley J.M., Grott M.W., Einstein M.E., Schutz M.M. Impact of Intake Water Temperatures on Reticular Temperatures of Lactating Dairy Cows. Journal of Dairy Science, vol. 91, 2008, pp. 3880-3887. 